\title{
Community-Based E-Government: Libraries as E-Government Partners and Providers
}

\author{
John Carlo Bertot \\ College of Information Studies \\ University of Maryland College Park \\ College Park, Maryland, United States \\ jbertot@umd.edu
}

\begin{abstract}
In the United States, e-government is a complex mix of federal, state, and local governments; technologies; service paradigms; and policies. There is no single approach to e-government, with a range of e-government applications and set of e-government technologies in effect. Agencies and levels of government have different mandates and approaches regarding e-government, leaving users on their own to identify and resolve their e-government needs. Without a bridge between previously mediated interactions, users often make their way to libraries and rely on librarian expertise to fulfill their e-government needs. This paper explores the ability of libraries and government agencies to collaborate effectively in the provision of e-government to residents and communities in this country, presenting findings from a national survey of U.S. public libraries, and interviews and case sites conducted with 15 public libraries in four states.
\end{abstract}

Keywords: Libraries, collaborative e-government, e-government partnerships.

\section{Introduction}

A key focus of e-government development has been on interactions between the government and members of the public, with many agencies now viewing egovernment as their primary method for interacting with members of the public $[1,2,4,5,6]$. Often, users seek access to e-government information to fulfill an important need, such as [7,8]: seeking unemployment benefits and other social services; registering to vote; renewing licenses; applying for jobs; paying taxes; enrolling children in school; applying for citizenship; scheduling appointments; and completing numerous other important federal, state, and local government functions online. Access to e-government is not just an issue of benefit to members of the public through direct services, however, as access to government information and services is a central premise of democracy and an informed citizenry.

A number of individuals, however, lack the means to access, understand, and use e-government. In many locations in the United States, the lack of availability of computers, Internet access, or even basic telecommunications infrastructure serve as barriers to access [26,27], and it is unclear as to whether investments in broadband 
infrastructure through the American Recovery and Reinvestment Act of 2009 will lead to increased broadband access and adoption. Nearly $40 \%$ of U.S. homes lack Internet access, and the percentage of households without Internet access jumps to $62 \%$ in rural communities. Among homes with Internet access, $45 \%$ lack broadband access, while $10 \%$ continue to rely on dial-up Internet service $[9,10]$. E-government access can be limited by difficulties in searching for and locating the desired information, lack of familiarity with the structure of government, lack of education about e-government, language barriers, and attitudes toward technology and government $[11,12,13]$.

At the same time, government agencies increasingly offer their services electronically - in some cases exclusively online. These agencies often direct users to public libraries for help when they need access or assistance [7]. Nearly all state departments of taxation only make printed forms available on request, requiring filers to request forms or access them online - and states and the federal government are strongly encouraging e-filing. Florida requires that individuals apply online for social service benefits from the Department of Children and Families (DCF) through AccessFlorida (http://www.myflorida.com/accessflorida/); and immigrant services (e.g., appointments, applications, status checking http://www.uscis.gov/portal/site/uscis) are increasingly online processes.

As a result of these gaps and challenges, members of the public seek assistance with e-government in libraries because they [5,7,14,15,16,17,18,19]: 1) lack access to computers and the Internet, which serve as a critical pre-requisite to engaging in egovernment transactions; 2) lack the technical skills to use the online services and resources; 3) lack and understanding of civics and are therefore unable to discern between federal, state, or local government services and/or which agencies are responsible for which e-government services; 4) are uncomfortable engaging in online interactions without guidance; 5) are unable to engage in e-government services due to the lack of accessibility and usability of government websites in general and egovernment services in particular; 6) often face a range of social barriers to accessing and using e-government services such as trust, language, and culture; and 7) are specifically directed by an agency to obtain assistance from a library as opposed to the actual agency providing the service.

In addition, people with other means of Internet access often still use e-government in public libraries because libraries and librarians have exceptionally high levels of social trust, making their guidance in accessing and using e-government uniquely trusted by residents $[18,20,21]$. Also, persons with Internet access in the home or elsewhere come to the library for assistance with e-government due to librarian expertise and the lack of available assistance from government agencies providing egovernment services. For example, Florida's DCF reduced the number of case workers and assistance providers by over 3,000 positions due to its implementation of the AccessFlorida online application system, resulting in near complete lack of available agency staff from which users can seek assistance [15].

In recognition of the reliance of residents on public libraries for e-government access, many federal, state, and local government agencies openly expect public libraries to provide residents with access to and guidance in using e-government, directing residents to the nearest public library for access and assistance [7,14,17,22]. Government agencies indicate that relying on libraries for e-government access and 
assistance allows agencies to focus on other issues [7,14,20]. Some local governments also engage public libraries to create and maintain the local government websites [17].

Whether viewed as an unfunded mandate or opportunity to extend e-government services through community-based institutions such as the public library, public libraries and governments are defacto collaborators in the provision of e-government services. The central issue, essentially unexplored, is the extent to which formal and deliberative collaborations can serve to create a robust and user-centered approach to e-government services.

\section{Methodology and Research Questions}

The findings presented in this paper rely on two data collection efforts: 1) a national survey of U.S. public libraries which collected data between September 2009 and November 2009; and 2) U.S. public library site visits and interviews which occurred between June 2009 and November 2009. The research questions that the study explored included: 1) What e-government service roles do public libraries provide to their communities? 2) What partnerships have libraries formed with government agencies in the provision of e-government services? 3) What are the success factors and/or barriers to forming partnerships with government agencies? 4) What are the challenges that libraries face by serving as e-government providers?

In the United States, there are approximately 16,500 public library buildings that are open to the public. Based on geographic dispersion and population service areas, everyone in the United States has access to a public library - though in certain regions such as the Southwest (i.e., New Mexico, Arizona), library facilities can be quite dispersed, requiring individuals to travel long distances to reach a library. Funded by the American Library Association and the Bill \& Melinda Gates Foundation, the survey drew a proportionate-to-size stratified random sample that considered the metropolitan status of the library (i.e., urban, suburban, and rural) and state in order to generate both national and state-level generalizeable estimates of public library Internet connectivity and service provision. The 2009 survey is the $12^{\text {th }}$ survey in a series of public library Internet access surveys conducted since 1994. The survey was Web-based, and sampled libraries received an announcement postcard regarding the survey. In all, the survey produced 7,393 responses, for a response rate of 82.4 percent. Weighted analysis is used to generate both state and national estimates. More specific methodology issues are available in [23].

Interviews and site visits were conducted with 15 libraries in four states. In all, the researcher visited 10 libraries and interviewed the library director in five additional libraries. Libraries were selected by geographic region (North, South, East, and West) as well as library characteristics such as metropolitan status (the same measures of metropolitan status used for the survey were used for site visit libraries), library size, number of staff, and known e-government library-agency partnerships. A Web search and literature review was conducted to ascertain the existence of library-government agency collaborative initiatives to the extent possible.

The combined national survey, interview, and site visit approach provided aggregate and generalizeable data regarding public library e-government service provision and challenges, while simultaneously allowing for on-the-ground 
assessments of library and government collaborative efforts. Moreover, the site visits allowed for an expansion and better understanding of the service context of libraryprovided e-government services, as the visits occurred during service hours, thus enabling the researcher to observe the services provided to users and the time of service delivery.

\section{Findings}

Nearly all U.S. public libraries - $99.0 \%$ - provide public access to the Internet. Through that access, libraries now devote a large amount of staff effort to education about e-government (see Table 1). In 2009, 78.7\% of public libraries provided direct assistance to patrons who applied for or accessing e-government services [28]. This percentage is a major increase in just one year, as only $54.1 \%$ of libraries reported providing this direct assistance in 2008 [24]. Along with direct assistance, $88.8 \%$ of libraries provided users with as-needed assistance in using and understanding egovernment resources. Libraries are often the only places that residents can turn for help, as the public library is the only provider of free public Internet and computer access in $66.0 \%$ of communities. Among patrons using e-government in libraries, 52.4\% did not own a computer, $42.4 \%$ lacked access both at home and at work, $40 \%$ were there because access is free, and $38.1 \%$ relied on the assistance of librarians [15]. Although a large percentage of libraries indicated that they provided a wide range of e-government services, $20.5 \%$ reported that they have partnerships with government agencies and other organizations. But this did represent an increase, as only $13.4 \%$ reported such partnerships in 2008 [24].

Libraries, however, met these e-government access and assistance needs in an increasingly difficult service environment:

- Due to the recession, library usage is increasing dramatically, with $75.7 \%$ of libraries reporting increased use of their public access workstations since last year, $71.1 \%$ reporting increased use of library wireless (wi-fi) services, and nearly $30.0 \%$ reporting increased use of library training services;

- Library funding is decreasing due to the recession, with decreases ranging from $1-10 \%$ in operating budgets;

- Public libraries report a decrease in service hours, with nearly $25 \%$ of urban public libraries reporting a decrease in the hours they are open;

- Public libraries - 58.6\% - report that they do not have enough staff to meet patron needs, do not have staff with the necessary expertise (46.0\%), and have too few workstations to meet demand (35.5\%); and

- The economic downturn is creating an increase in both employment services and e-government services, which go hand-in-hand due to government unemployment social benefits and the need to seek employment in order to move off government benefits.

This context challenges libraries as they provide e-government services without support and a mandate to do so - and yet, it offers an opportunity to engage in more collaborative approaches to e-government that leverage library and government resources. 
Table 1. E-Government Roles and Services Provided by Public Libraries by Metropolitan Status

\begin{tabular}{|c|c|c|c|c|}
\hline & \multicolumn{3}{|c|}{ Metropolitan Status } & \\
\hline E-Government roles and services & Urban & Suburban & Rural & Overall \\
\hline $\begin{array}{l}\text { Staff provide assistance to patrons } \\
\text { applying for or accessing e- } \\
\text { government services }\end{array}$ & $\begin{array}{c}75.9 \% \\
(n=1,913)\end{array}$ & $\begin{array}{c}78.6 \% \\
(n=3,820)\end{array}$ & $\begin{array}{c}79.9 \% \\
(n=5,383)\end{array}$ & $\begin{array}{c}78.7 \% \\
(n=11,116)\end{array}$ \\
\hline $\begin{array}{l}\text { Staff provide as needed assistance } \\
\text { to patrons for understanding how to } \\
\text { access and use e-government Web } \\
\text { Sites }\end{array}$ & $\begin{array}{c}91.2 \% \\
(n=2,300)\end{array}$ & $\begin{array}{c}88.8 \% \\
(n=4,317)\end{array}$ & $\begin{array}{c}87.9 \% \\
(n=5,918)\end{array}$ & $\begin{array}{c}88.8 \% \\
(n=12,535)\end{array}$ \\
\hline $\begin{array}{l}\text { Staff provide assistance to patrons } \\
\text { for understanding government } \\
\text { programs and services }\end{array}$ & $\begin{array}{c}45.6 \% \\
(n=1,149)\end{array}$ & $\begin{array}{c}45.6 \% \\
(n=2,215)\end{array}$ & $\begin{array}{c}40.7 \% \\
(n=2,742)\end{array}$ & $\begin{array}{c}43.3 \% \\
(n=6,106)\end{array}$ \\
\hline $\begin{array}{l}\text { Staff provide assistance to patrons } \\
\text { for completing government forms }\end{array}$ & $\begin{array}{c}71.4 \% \\
(n=1,800)\end{array}$ & $\begin{array}{c}65.2 \% \\
(n=3,168)\end{array}$ & $\begin{array}{c}65.1 \% \\
(n=4,386)\end{array}$ & $\begin{array}{c}66.3 \% \\
(n=9,354)\end{array}$ \\
\hline $\begin{array}{l}\text { The library developed guides, tip } \\
\text { sheets, or other tools to help } \\
\text { patrons use e-government websites } \\
\text { and services }\end{array}$ & $\begin{array}{l}23.3 \% \\
(n=588)\end{array}$ & $\begin{array}{c}18.7 \% \\
(n=907)\end{array}$ & $\begin{array}{c}14.2 \% \\
(n=957)\end{array}$ & $\begin{array}{c}17.4 \% \\
(n=2,452)\end{array}$ \\
\hline $\begin{array}{l}\text { The library offers training classes } \\
\text { regarding the use of government } \\
\text { Web sites, understanding } \\
\text { government programs, and } \\
\text { completing electronic forms }\end{array}$ & $\begin{array}{l}22.9 \% \\
(n=578)\end{array}$ & $\begin{array}{c}7.3 \% \\
(n=357)\end{array}$ & $\begin{array}{c}4.8 \% \\
(n=321)\end{array}$ & $\begin{array}{c}8.9 \% \\
(n=1,256)\end{array}$ \\
\hline $\begin{array}{l}\text { The library offered translation } \\
\text { services for forms and services in } \\
\text { other languages }\end{array}$ & $\begin{array}{l}11.1 \% \\
(n=279)\end{array}$ & $\begin{array}{c}6.6 \% \\
(n=321)\end{array}$ & $\begin{array}{c}4.2 \% \\
(n=280)\end{array}$ & $\begin{array}{c}6.2 \% \\
(n=880)\end{array}$ \\
\hline $\begin{array}{l}\text { The library is partnering with } \\
\text { government agencies, non-profit } \\
\text { organizations, and others to provide } \\
\text { e-government services }\end{array}$ & $\begin{array}{l}26.4 \% \\
(n=666)\end{array}$ & $\begin{array}{c}21.2 \% \\
(n=1,030)\end{array}$ & $\begin{array}{c}17.8 \% \\
(n=1,201)\end{array}$ & $\begin{array}{c}20.5 \% \\
(n=2,898)\end{array}$ \\
\hline $\begin{array}{l}\text { The library is working with } \\
\text { government agencies (local, state, } \\
\text { or federal) to help agencies } \\
\text { improve their websites and/or e- } \\
\text { government services }\end{array}$ & $\begin{array}{l}11.0 \% \\
(n=277)\end{array}$ & $\begin{array}{c}8.2 \% \\
(n=398)\end{array}$ & $\begin{array}{c}6.0 \% \\
(n=405)\end{array}$ & $\begin{array}{r}7.7 \% \\
(n=1,080)\end{array}$ \\
\hline $\begin{array}{l}\text { The library has at least one staff } \\
\text { member with significant knowledge } \\
\text { and skills in provision of e- } \\
\text { government services }\end{array}$ & $\begin{array}{l}31.5 \% \\
(n=794)\end{array}$ & $\begin{array}{c}16.2 \% \\
(n=789)\end{array}$ & $\begin{array}{c}15.4 \% \\
(n=1035)\end{array}$ & $\begin{array}{c}18.5 \% \\
(n=2,618)\end{array}$ \\
\hline Other & $\begin{array}{c}4.8 \% \\
(n=121)\end{array}$ & $\begin{array}{c}3.3 \% \\
(n=159)\end{array}$ & $\begin{array}{c}4.4 \% \\
(n=298)\end{array}$ & $\begin{array}{c}4.1 \% \\
(n=578)\end{array}$ \\
\hline
\end{tabular}

The site visits and interviews identified and explored a number of library/government agency projects, including:

- The Alachua County Library District in Florida, which partnered with the Florida Department of Children and Families, as well as community organizations, to create The Library Partnership (http://www.acld.lib.fl.us/locations/the-librarypartnership). The library provides space within libraries for agencies devoted to child welfare to offer assistance with accessing e-government forms and 
applications used by the organizations providing services at the center, as well as homework help, GED and literacy classes.

- The Austin Public Library in Texas, which partnered with the U.S. Citizenship and Immigration Services (USCIS) agency to create its New Immigrants Centers to provide resources and support for immigrants. These Centers provide a range of support services in multiple languages, including citizenship courses and test preparation.

- The Hartford Public Library in Connecticut, which partnered with the USCIS to create The American Place to provide resources and support for immigrants, particularly those seeking U.S. Citizenship.

- The public libraries in Georgetown County South Carolina, which collaborated with the state Department of Emergency Management on Web 2.0 materials - including video-game simulations, social media, oral-history video interviews, digital storytelling, and the creation of a digital collection of historic hurricane views - to record the history of Hurricane Hugo (http://georgetowncountylibrary.sc.gov/randompages/hurricane.htm) and help the community respond to emergency situations.

These examples demonstrate just some of the types of collaborations between libraries and government agencies. Table 2 provides examples of additional librarygovernment (and other) e-government collaborations.

Table 2. Sample Public Library-Government E-government Partnerships

\begin{tabular}{|l|l|l|}
\hline Project Title & Partnership & Description \\
\hline $\begin{array}{l}\text { Queens Library } \\
\text { Health Link }\end{array}$ & $\begin{array}{l}\text { Queens Library } \\
\text { National Institute of Health }\end{array}$ & $\begin{array}{l}\text { Queens Library Health Link program is designed to } \\
\text { test the efficacy of a comprehensive participatory } \\
\text { research approach to reduce disparities by improving } \\
\text { the use of cancer prevention, screening and } \\
\text { treatments interventions. In this project, public library } \\
\text { branches provide a base for neighborhood } \\
\text { organizing, education, data gathering, planning and } \\
\text { implementation of local health promotion } \\
\text { experiments and dissemination of results, working } \\
\text { with 42 of the 63 branch libraries in Queens. }\end{array}$ \\
\hline $\begin{array}{l}\text { California Health } \\
\text { Resources }\end{array}$ & $\begin{array}{l}\text { California Healthcare } \\
\text { Foundation; National } \\
\text { Network of Libraries of } \\
\text { Medicine; Pacific } \\
\text { Southwest Region; } \\
\text { California Public Libraries }\end{array}$ & $\begin{array}{l}\text { Phase one of a potential multi-year effort to build the } \\
\text { capacity of California's public libraries to provide } \\
\text { reliable consumer health information. Libraries will } \\
\text { also be positioned as model environments } \\
\text { supporting healthy lifestyle choices. }\end{array}$ \\
\hline $\begin{array}{l}\text { Passport Application } \\
\text { Acceptance Facility }\end{array}$ & $\begin{array}{l}\text { East Brunswick Public } \\
\text { Library and the U.S. State } \\
\text { Department }\end{array}$ & $\begin{array}{l}\text { The East Brunswick Public Library is an officially } \\
\text { designated passport application acceptance facility } \\
\text { with passport processing hours. }\end{array}$ \\
\hline $\begin{array}{l}\text { Solar Test Bed } \\
\text { Project }\end{array}$ & $\begin{array}{l}\text { Fayetteville Public Library; } \\
\text { the city of Fayetteville, } \\
\text { University of Arkansas; } \\
\text { Arkansas Energy Office; } \\
\text { American Electric Power; } \\
\text { National Center for } \\
\text { Reliable Electric Power } \\
\text { Transmission; others }\end{array}$ & $\begin{array}{l}\text { The partnership will design, install, and operate a } \\
\text { solar-generated energy system to support a test } \\
\text { environment for solar-energy products created within } \\
\text { the local economy. This project will position the } \\
\text { library as the city's incubator for local solar business } \\
\text { development and stimulate Fayetteville's fledgling } \\
\text { green businesses, as well as promote citizen interest } \\
\text { in adopting solar technologies. }\end{array}$ \\
\hline \multicolumn{2}{|l}{}
\end{tabular}


The partnerships varied in degree and scope. The Alachua County Library District partnership, for example, was an embedded and integrative partnership. The library served as the central hub of the government service, providing space, librarian expertise, agency expertise, and a range of information support services designed to meet the needs of those seeking e-government services. In this sense, the library and agencies formed a collaborative approach to engaging in egovernment service provision and access that maximized the strengths of each partnership participant.

The Austin and Hartford Public Library collaboration differed in nature. Through coordination with USCIS, the libraries assisted USCIS develop a range of informational resources and built services around immigration and citizenship. It is, however, the libraries that provide the training classes and assist the immigrant populations that they serve. The libraries in essence serve as facilitators of immigration and citizenship e-government services.

The South Carolina libraries in Georgetown County collaboration is yet another type of partnership in which the library serves in both a cultural role in terms of historical preservation of government information as well as an emergency response role that facilitates community recovery efforts in the event of an emergency.

Given the limitation of the site visits and the wide range of partnerships and collaborations found, it is clear that collaborations between libraries and government agencies take many forms and can evolve in different ways. There are preliminary indications that there is a continuum of library-government e-government partnerships that require additional exploration.

The site visits and interviews also identified both benefits and barriers to librarygovernment partnerships. Identified benefits included:

- The ability to provide combine services with public access technologies and Internet access, which many of the users lacked elsewhere;

- The ability to embed e-government services within a trusted and neutral community organization such as the public library;

- The ability to create an integrated service environment that cut across multiple agency services and benefits, as individuals often required multiple e-government interactions provided by different levels of government and agencies; and

- The librarian, whom served as an intermediary between e-government services and the user.

Identified challenges included:

- Agencies, due to mandates and service authority constraints, focused on their own services and did not necessarily view the entire e-government spectrum that libraries faced in a public access service context;

- Partnerships are often associated with risk due to public scrutiny, and agencies were loathe to form partnerships and accept the risks that could manifest through partnerships;

- When willing to engage in partnerships, some agencies viewed the library as a means through which to offload agency workload rather than create a truly collaborative e-government service approach; and

- Partnerships were evolutionary in nature, as both libraries and agencies learned over time the best ways to approach their collaborations. 
As discussed below, there are benefits, challenges, and issues associated with forging government-library partnerships.

\section{Key Issues and Challenges}

Key findings from the research studies identified above indicated that there are numerous factors that affect the degree to which a library can successfully provide egovernment services, such as staff skills and knowledge, staff time commitments, resource constraints, availability of workstations, and broadband. More specifically, these service challenges included:

- Libraries often lack wide-scale coordination with critical e-government service agencies (e.g., immigration, taxes, health, social services) which users most frequently seek;

- Librarians do not necessarily have expertise in the range of e-government services, resources, or applications necessary for users to access and successfully participate;

- Librarians may not understand the larger policy/governance/jurisdictional context of e-government (e.g., immigration policy; tax law; federal, state, local government);

- Library e-government roles, which can vary from library to library, have yet to be clearly defined and differentiated in light of local situational factors - though some libraries have clearly embraced the e-government service role through innovative practices and support structures;

- Libraries face a range of constraints, including insufficient number of computers to meet patron needs; budgetary, space, and infrastructure challenges; and inadequate bandwidth to meet increasingly bandwidth-heavy e-government services;

- Libraries experienced a significant increase in usage as a result of the recession; and

- Libraries are a service provider at the end of a vast e-government service environment that, at the federal level alone, encompasses more than 30,000 websites and well over 100 million pages [25].

The site visits and interviews provided, however, indications that collaborative egovernment, based on agency and library partnerships, can ultimately create a comprehensive community-based approach to e-government service provision.

But these partnerships seem to occur on a continuum from a library simply serving as a public access point to workstations and the Internet all the way to a fully integrated government-library service outlet housed in the library - around which the library builds a range of information and staff support services. Given the exploratory nature of this research, it is not possible to codify or fully determine this emerging collaborative continuum.

The site visits also identified a range of success factors for these collaborations:

- $\quad$ Both the library and the agency saw mutual benefit to entering into a partnership designed to provide collaborative e-government services; 
- Agencies viewed the partnerships as ways through which to extend e-government services to the intended service recipients through libraries, rather than as a means to shift service provision costs to libraries;

- Agencies considered the library a true partner and considered librarian feedback regarding e-government service design and delivery;

- Agencies were willing to help librarians better understand the e-government services, resources, and technologies;

- Agencies provided library-specific support (i.e., a separate help e-mail and phone number) through which librarians could contact agency staff for assistance;

- The library considered providing e-government services as part of its mission to serve the public; and

- The library built a support infrastructure (e.g., information resources, technology training, staff assistance) around the e-government services.

These success factors require additional testing and verification through additional research, but seemed to permeate the site visit and interview partnerships.

\section{Conclusion}

This paper presented the results of a national survey, site visits, and interviews regarding the provision of e-government services in U.S. public libraries. The exploratory research indicated that government-library collaborations can extend egovernment services into communities and ensure that e-government services and resources are available to and inclusive of all members of society. The research identified critical roles that public libraries offer to their users, but also identified success factors for successful collaborations between government agencies and libraries. The research also identified, however, a range of challenges that public libraries face as providers of e-government services. Additional research is necessary to more fully understand the complexity, benefits, and challenges to library and government collaborations to promote the adoption and use of e-government services to the greatest extent possible.

Acknowledgment. Funding for this study was provided in part by the American Library Association and the Bill \& Melinda Gates Foundation.

\section{References}

1. Bertot, J.C., Jaeger, P.T.: User-centered e-government: Challenges and benefits for government Web sites. Government Information Quarterly 23, 163-168 (2006)

2. Bertot, J.C., Jaeger, P.T.: The e-government paradox: Better customer service doesn't necessarily cost less. Government Information Quarterly 25, 149-154 (2008)

3. Dawes, S.S.: Governance in the digital age: A research and action framework for an uncertain future. Government Information Quarterly 26, 257-264 (2009)

4. Ebbers, W.E., Pieterson, W.J., Noordman, H.N.: Electronic government: Rethinking channel management strategies. Government Information Quarterly 25, 181-201 (2008) 
5. Jaeger, P.T., Bertot, J.C.: Designing, implementing, and evaluating user-centered and citizen-centered e-government. International Journal of Electronic Government Research (in press)

6. Streib, G., Navarro, I.: Citizen demand for interactive e-government: The case of Georgia consumer services. American Review of Public Administration 36, 288-300 (2006)

7. Bertot, J.C., Jaeger, P.T., Langa, L.A., McClure, C.R.: Public access computing and Internet access in public libraries: The role of public libraries in e-government and emergency situations. First Monday 11(9) (2006),

http://www.firstmonday.org/issues/issue11_9/bertot/index.html

8. McClure, C.R., Jaeger, P.T., Bertot, J.C.: The looming infrastructure plateau?: Space, funding, connection speed, and the ability of public libraries to meet the demand for free Internet access. First Monday, 12(12) (2007), http://www.uic.edu/htbin/cgiwrap/bin/ojs/index.php/ $\mathrm{fm} /$ article/view/2017/1907

9. Horrigan, J.B.: Home broadband adoption 2008: Adoption stalls for low-income Americans even as many broadband users opt for premium services that give them more speed. Pew Internet and American Life Project, Washington, D.C. (2008)

10. Horrigan, J.B.: Obama's online opportunities II: If you build it, will they log on? Pew Internet and American Life Project, Washington, D.C. (2009)

11. Fenster, M.: The opacity of transparency. Iowa Law Review 91, 885-949 (2006)

12. Jaeger, P.T., Thompson, K.M.: E-government around the world: Lessons, challenges, and new directions. Government Information Quarterly 20(4), 389-394 (2003)

13. Jaeger, P.T., Thompson, K.M.: Social information behavior and the democratic process: Information poverty, normative behavior, and electronic government in the United States. Library \& Information Science Research 26(1), 94-107 (2004)

14. Bertot, J.C., Jaeger, P.T., Langa, L.A., McClure, C.R.: Drafted: I want you to deliver egovernment. Library Journal 131(13), 34-39 (2006)

15. Gibson, A.N., Bertot, J.C., McClure, C.R.: Emerging role of public librarians as Egovernment providers. In: Sprague Jr., R.H. (ed.) Proceedings of the 42nd Hawaii International Conference on System Sciences, pp. 1-10 (2009) doi:10.1109/HICSS.2009.183

16. Jaeger, P.T.: User-centered policy evaluations of Section 508 of the Rehabilitation Act: Evaluating e-government websites for accessibility. Journal of Disability Policy Studies 19(1), 24-33 (2008a)

17. Jaeger, P.T.: Public libraries and local e-government. In: Reddick, C.G. (ed.) Handbook on research on strategies for local e-government adoption and implementation: Comparative studies, pp. 647-660. IGI Global, Hershey (2009)

18. Jaeger, P.T., Fleischmann, K.R.: Public libraries, values, trust, and e-government. Information Technology and Libraries 26(4), 35-43 (2007)

19. Jaeger, P.T., Langa, L.A., McClure, C.R., Bertot, J.C.: The 2004 and 2005 Gulf Coast hurricanes: Evolving roles and lessons learned for public libraries in disaster preparedness and community services. Public Library Quarterly 25(3/4), 199-214 (2007)

20. Fisher, K.E., Becker, S., Crandall, M.: E-government service use and impact through public libraries: Preliminary findings from a national study of public access computing in public libraries. In: Proceedings of the 43rd Hawaii International Conference on System Sciences, pp. 1-10 (2010)

21. Heanue, A.: In support of democracy: The library role in public access to government information. In: Kranich, N. (ed.) Libraries \& Democracy: The Cornerstones of Liberty, pp. 121-128. American Library Association, Chicago (2001) 
22. Jaeger, P.T., Bertot, J.C.: E-government education in public libraries: New service roles and expanding social responsibilities. Journal of Education for Library and Information Science 50, 40-50 (2009)

23. Bertot, J.C., Langa, L.A., Grimes, J., Simmons, S.N., Sigler, K.: 2009-2010 Public Library Funding and Technology Access survey: Survey Results and Findings. Center for Library and Information Innovation, College Park (2010), http://www. liicenter.org/plinternet/

24. American Library Association: Libraries Connect Communities 3: Public Library Funding \& Technology Access Study 2008-2009. American Library Association, Chicago (2009), http: / /www.ala.org/plinternetfunding/

25. Evans, K.: E-government and information technology for the federal government. Talk presented at the Center for Information Policy and Electronic Government, University of Maryland (2007)

26. Bertot, J.C.: The multiple dimensions of the digital divide: More than technology 'haves' and 'have-nots'. Government Information Quarterly 20, 185-191 (2003)

27. Bertot, J.C.: Public access technologies in public libraries: Impacts and implications. Information Technology \& Libraries 28(2), 84-95 (2009)

28. American Library Association: Libraries Connect Communities: Public Library Funding \& Technology Access Study 2009-2010. American Library Association, Chicago, Available when published, http://www.ala.org/plinternetfunding/ (forthcoming 2010a) 